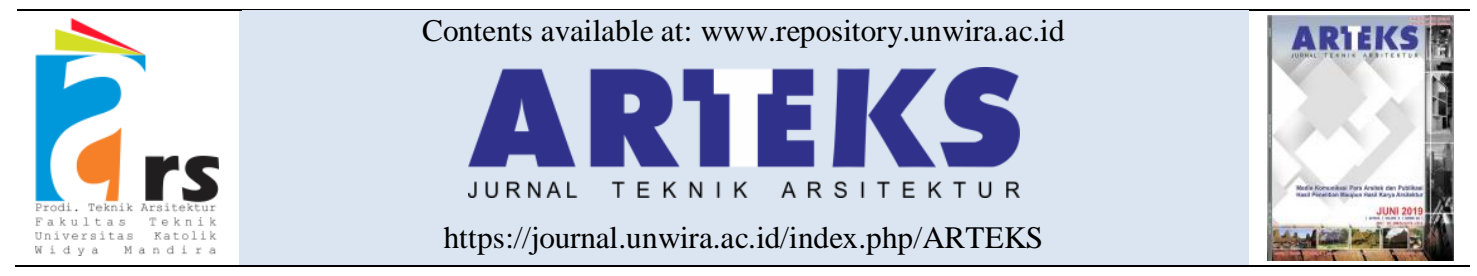

Research paper

doi: $10.30822 /$ arteks.v5i3.540

\title{
The implementation of traditional Balinese architecture in the art theater of Badung Regency
}

\section{Alan Darma Saputra, Rahadhian Prajudi Herwindo*(D), Yohanes Karyadi Kusliansjah}

Architecture Study Program, Faculty of Engineering, Universitas Katolik Parahyangan

Jl. Ciumbuleuit no. 94, Bandung, Indonesia

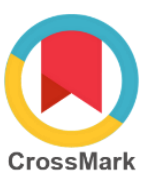

\begin{tabular}{l}
\hline ARTICLE INFO \\
\hline Article history: \\
Received May 21, 2020 \\
Received in revised form May 30, 2020 \\
Accepted July 27, 2020 \\
Available online December 01, 2020
\end{tabular}

ABSTRACT

Bali Island is a famous tourist destination in the world and this has made it a gathering hub and multicultural meeting center for tourists from several countries, thereby, raising concern on the possibility of the area losing its traditional Balinese architecture. It is necessary to make adjustments by adopting the shape of the old Balinese building. This means the emergence of new functions is not a taboo but a new design challenge, therefore, the traditional Balinese architecture and theater provisions were combined to produce a neo-vernacular architecture by using descriptive qualitative method. This led to the application of asta kosala-kosali in the theater space, modification on the roof, body and legs shape of the Balinese building, and the integration of the construction system and materials in the Balinese theater architecture.

*Corresponding author: Rahadhian Prajudi Herwindo

Department of Architecture, Faculty of Engineering, Universitas Katolik Parahyangan, Indonesia

Email: dodo@unpar.ac.id

ORCID: https://orcid.org/0000-0003-3756-

3707

\section{Introduction}

Bali is one of the most famous islands in Indonesia and this often makes it a destination for foreign tourists from all over the world. In the last 2 years, the number of tourists visiting the area has reached over fifteen million due to its beauty. Several local and foreign investors saw the potential of this island and invested in it using new and more modern infrastructures (Sunarta and Arida 2017). This is, however, affected the cultural artifacts and ideological values of the people (Lake, Purbadi, and Harmans 2020).

Several questions have been asked due to the confusion felt about the parts of the building that originate from Bali and those from outside because the current architectural form tends to be singular and has lost the local architectural identity (Lake 2014; 2015; Lake et al. 2020).

This was observed to be caused by several new functions added over time which has made the building to be more diverse but often with the wrong application of modern architecture, thereby, reducing the existing local values (Salura and Lake 2014; Lake 2016; 2017). Moreover, the implementation of an international style in the form of new buildings makes society more concerned with aspects of function rather than the ideology and identity (Hitchcock 1997). Balinese architecture is, however, expected to focus on building according to the customs and provisions of the Hindus (bali.com, n.d.). 
There is a need to mix form, variety, and values of local culture to maintain a balance between culture and technology (Wijaya 2016). This can be conducted by integrating the old Balinese buildings form with more modern functions (Antoniades 1990). This, therefore, means having new functions is not a taboo but rather a challenge for new designs in Balinese architecture.

This process was applied within the scope of neo-vernacular architectural styles which serves as a container to update physical appearances including building forms and structures and nonphysical ones such as history, symbols, and meanings to meet current needs (Arifin 2017).

The purpose of this study was to find a meeting point between Traditional Balinese Architecture and a new building function, theater. The results are expected to be a guideline to implement Balinese architecture in wide-span buildings.

\section{Method}

The research was conducted using a qualitative method with observations and case study assessments from a subjective perspective used to determine a meeting point between Balinese culture and the technology needed by the theater.

In qualitative research, researchers act as the research instruments and are expected to have an understanding of the theory and broad insight required to ask, analyze, photograph, construct, and ensure the social situation under study becomes clearer and meaningful (Sugiyono 2019).

A descriptive approach was employed and this involves interpreting existing conditions such as situations, activities, influences, and analyzing the study without making broader conclusions (Sugiyono 2019).

The art theater in Badung Regency was selected for the Balinese architecture implementation due to its potential and the need for art space in the area according to data from the RPJMD (Medium Term Development Plan) in Badung City. Meanwhile, it also has the potential to describe the integration of traditional Balinese architecture with new functions to produce modern art theater.

Procedurally, this research was divided into 3 parts including:
1. The first stage was the introduction to the concepts and theories of traditional Balinese architecture such as spatial planning, form, connections, and materials. Therefore, the spirit inside the original Balinese building can be applied in future buildings.

2. The second stage involved adjusting the theater regulations starting from the theater space, stage form, stands, panel form as well as reflecting and dampening fields.

3. The last stage was integrating Balinese architecture and theater functions packaged within the scope of neo-vernacular architecture after which important aspects and points were observed to be used later as guidelines.

The traditional elements in this study were guided by the concept of traditional Balinese form which is a microcosm of the macrocosm. The community is observed to have rituals such as the Tri Mandala and Sanga Mandala spatial patterns and, in terms of appearance, 3 parts such as the head, body, and legs were identified as well as their construction and relationship with the environment (Gelebet 1985).

Meanwhile, theater guidelines were based on Appleton and this involved analyzing the relationship between spaces within the theater, shape of the auditorium and the stands, construction, and materials, as well as the noise provisions in the environment (Appleton 2012).

These two guidelines were integrated into a neo-vernacular architecture which encompasses physical and non-physical aspects such as location layout, the shape of buildings, materials, and construction. These elements are used as a response to nature in the old traditional buildings by displaying them in modern buildings (Loebis 2004).

The scope of this research was the Bali Island, precisely in the Badung Regency (figure 1). This area was selected because the government center tends to be new and this means it does not have complete facilities including the art theater. The location is also far from other theaters and this means one needs to be constructed there to equalize the facilities. 


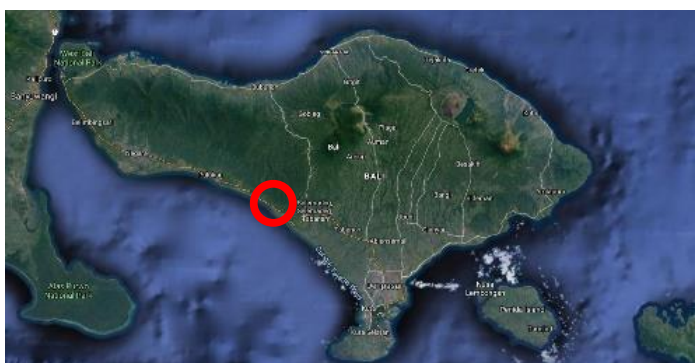

Figure 1. The location of Bali Island

\section{Result and discussion}

\section{Spatial pattern}

There are spatial rules in Balinese architecture such as Tri Mandala which is for the division of 3 rooms and Sanga Mandala for 9 rooms designed to divide space based on hierarchical level. It is also possible to observe Tri Mandala horizontally or based on differences (figure 2). This is due to the fact that each flat field has its function as shown in the bottom section and divided based on the hierarchy level such that a higher building has more important value for space. Furthermore, the sacred part requires the structure faces the mountain.

Balinese spatial pattern

The importance level of tri mandala
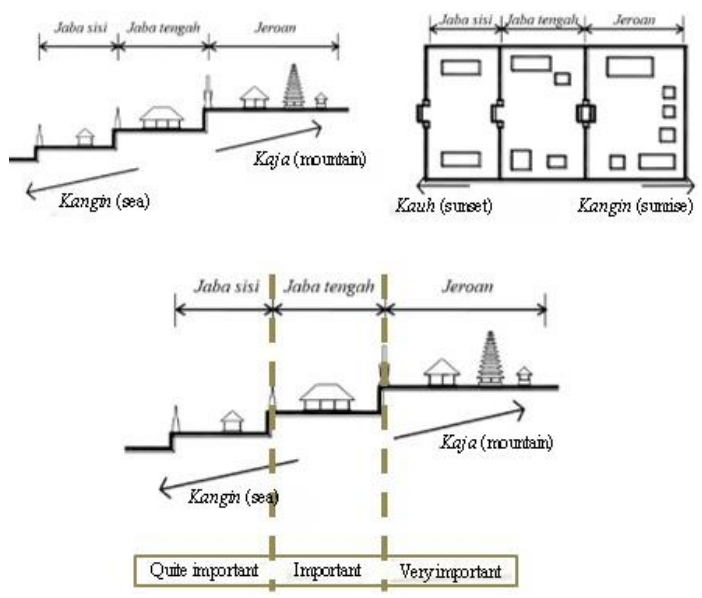

Figure 2. The level of tri mandala Source: (Suryada 2012)

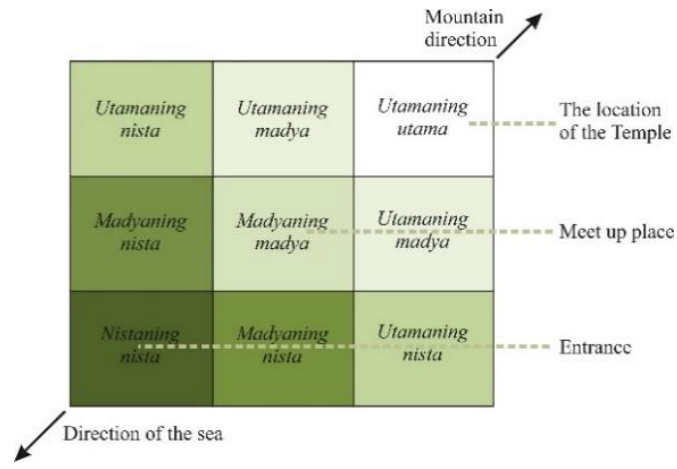

Figure 3. The division of sanga mandala Source: (Suryada 2012)

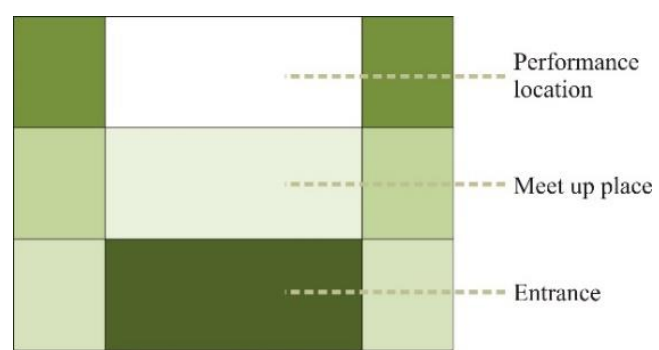

Figure 4. Hierarchy of theater room Source: (Doelle 1972)

The other spatial provisions contained in the theater, however, prioritize relationships between spaces and this means several functions are expected to be close together.

The implementation of spatial aspects

After adopting the spatial structure of Balinese architecture and theater, the following conclusions were made (figure 5):

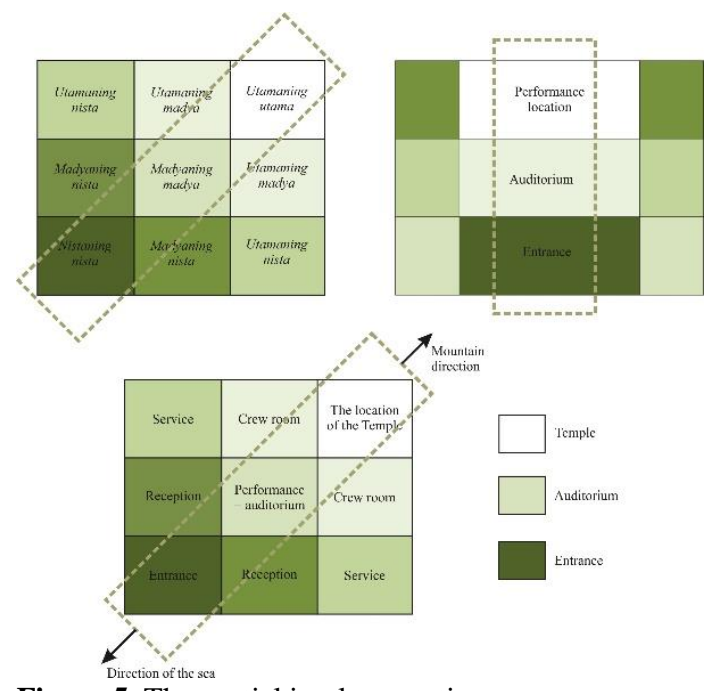

Figure 5. The spatial implementation 
The spatial hierarchy of each variable is, therefore, expected to be fulfilled.

\section{Sosok (figure)}

The sosok or figure in Bali is divided into the following:

\section{Roof (head)}

This illustrates the relationship with God and this means Bali residents are expected to use a traditional Balinese roof (figure 6).

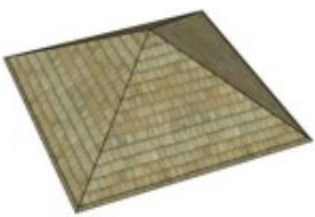

Limas roof
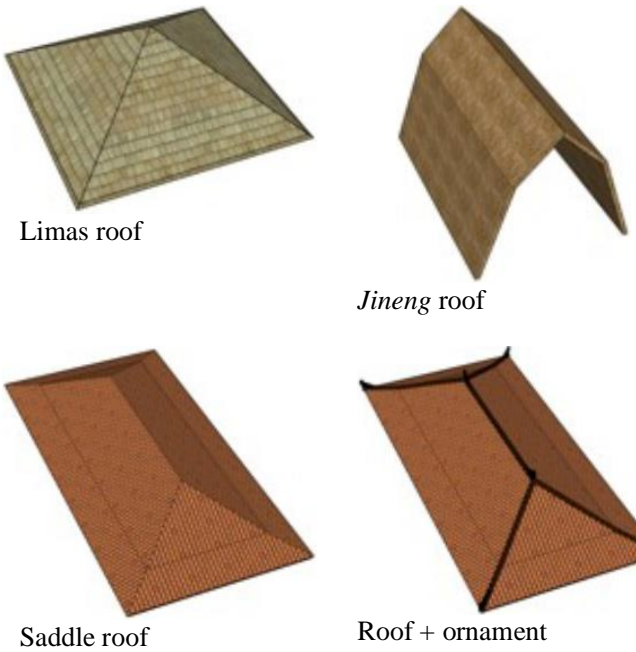

Figure 6. Roof figure in Bali Source: (Made 2012)

\section{Covers (body)}

These tend to be closed but open and assisted by wooden poles in a space consisting of many people such as bale and gathering place (figure 7).

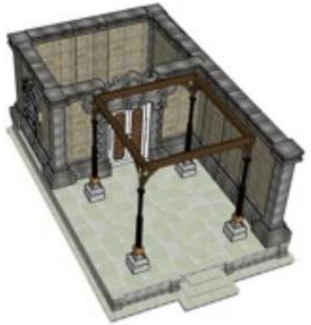

Closed scope

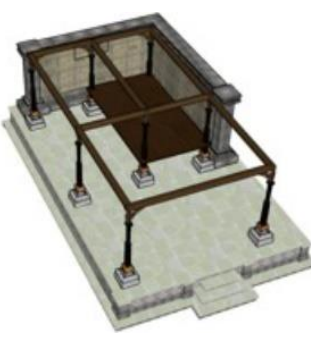

Open scope

Figure 7. Covers figure in Bali

Source: (Made 2012)

\section{Basic building (legs)}

The bottom of the building is constructed to be higher from the ground to ensure water does not enter the house and also to serve as the leg of the building (figure 8 ).
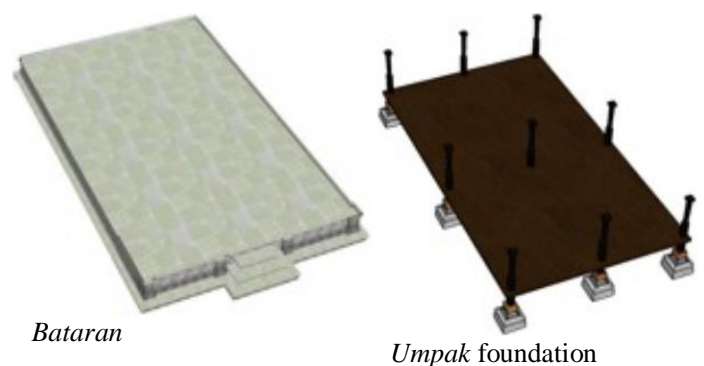

Figure 8. The legs figure of a Balinese building Source: (Made 2012)

The figure of the theater

The theater figure is more focused on the form of the stage and the fan-shaped stands as well as the covers to muffle or reflect sound (figure 9).

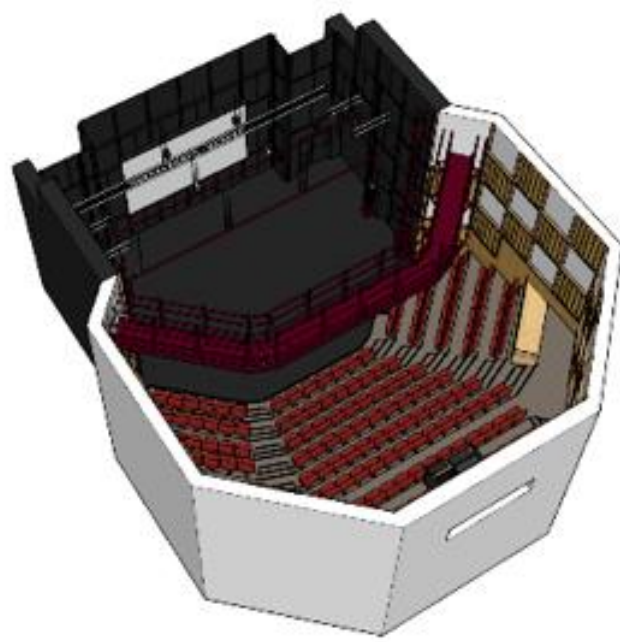

Figure 9. The covers figure in auditorium Source: (Appleton 2012)

The implementation of figure aspects.

This can be conducted using several things as shown in the following images (figure 10):

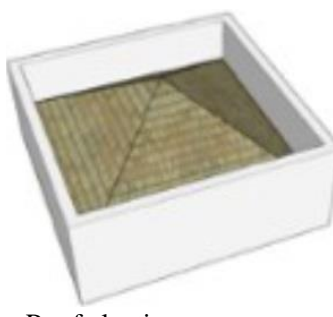

Roof planting

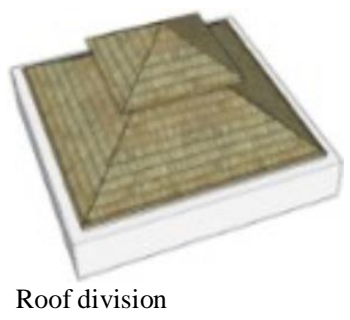




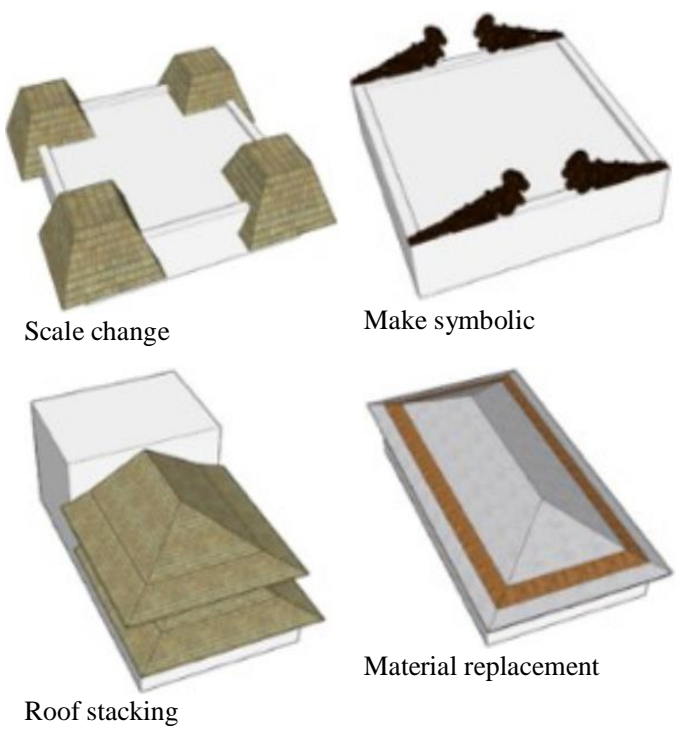

Figure 10. The implementation of the roof figure

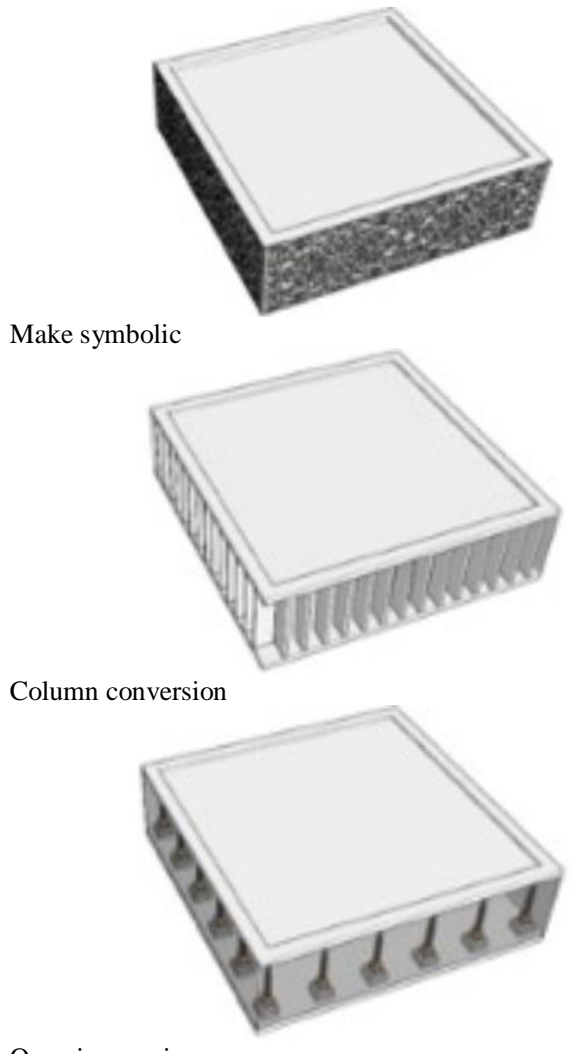

Open impression

Figure 11. The implementation of the covers figure

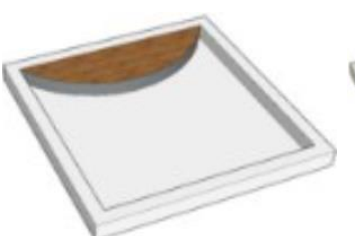

Space in batara

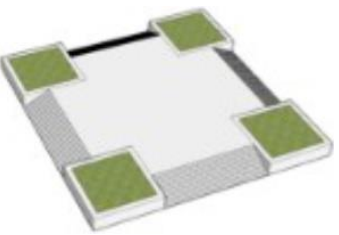

Modify access

Figure 12. The implementation of the legs figure

\section{System}

Bali construction system

Several basic constructions systems are commonly used in Bali with most of the material used selected from the surrounding nature such as natural stone, wood, fibers, and others. These are, however, sometimes not in accordance with today's safety standards, especially with respect to fire incidence.

Table 1. Bali construction system

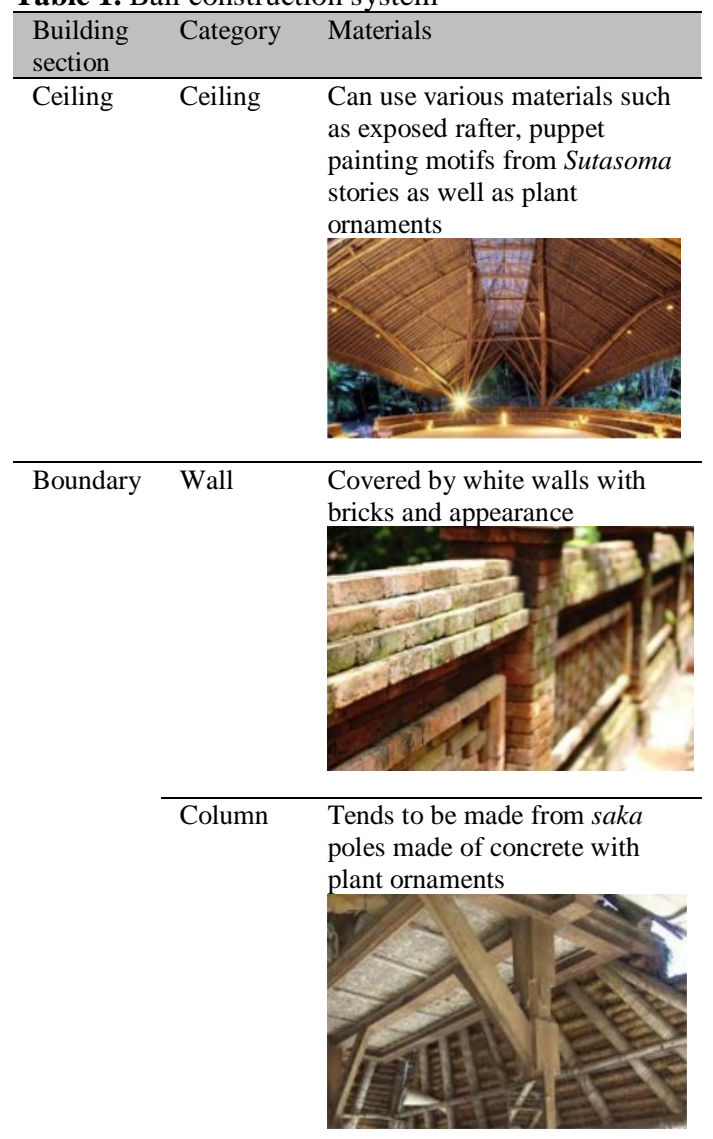

Source: (Sunarta and Arida 2017)

\section{Theater system}

Theater construction is more focused on modern materials in relation to the existing sound system such as the use of prefabricated panels, 
STC, gypsum, wood with finishing, fiber, concrete, and others. Furthermore, the use of concrete and brick is also dominant to ensure security in the building.

Table 2. Theater acoustic systems

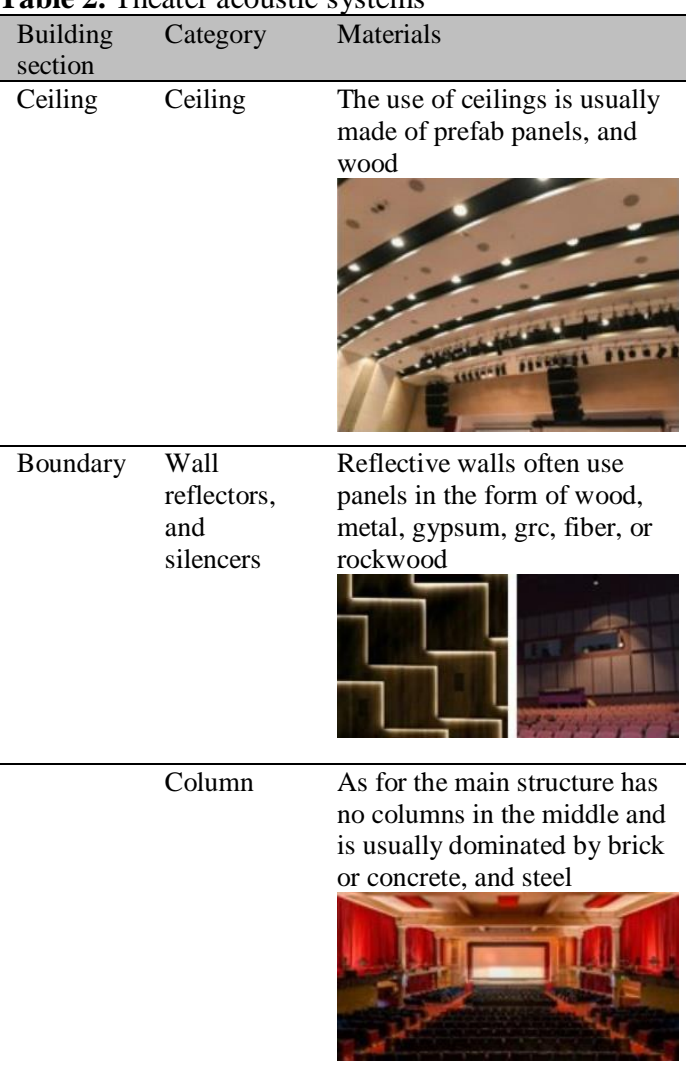

Source: (De Chiara 1973)

The implementation of system aspects

This involves combining the construction of Balinese Architecture with new materials needed by the theater to ensure it is safer and in accordance with existing acoustic requirements.

Table 3. The combination of the theater system

\begin{tabular}{lll}
\hline $\begin{array}{l}\text { Colaboration of Bali construction } \\
\text { system and modern theater }\end{array}$ & Combination \\
\hline Bali construction & $\begin{array}{l}\text { Theater } \\
\text { construction }\end{array}$ & Results \\
\hline & $\begin{array}{l}\text { The } \\
\text { combination of } \\
\text { faux wood } \\
\text { materials can } \\
\text { reduce the } \\
\text { destruction of } \\
\text { the } \\
\text { environment, } \\
\text { and glass can } \\
\text { display the } \\
\text { expression of }\end{array}$ \\
\hline
\end{tabular}

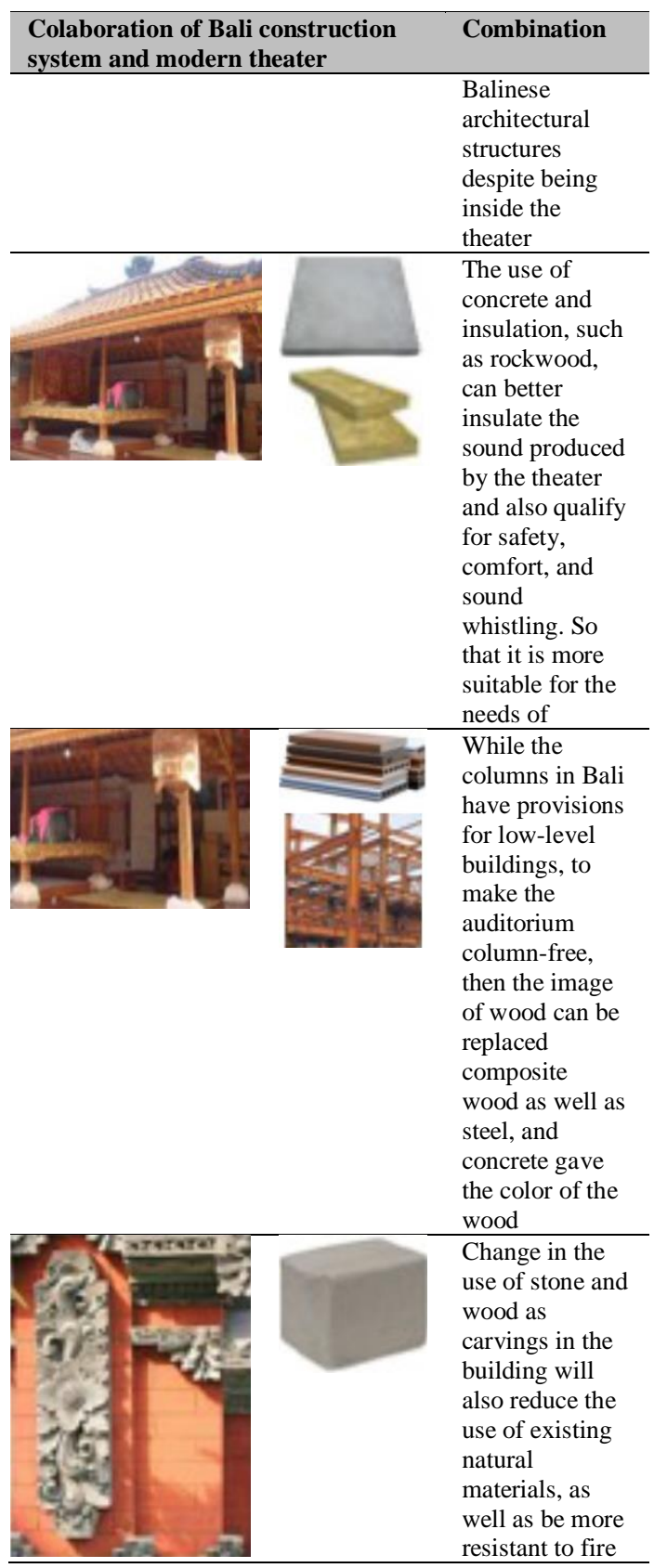

\section{Environment}

Bali location

The use of natural materials is a manifestation of the existing environment and the answer to the tropical climate as observed in the application of the traditional Balinese roof to protect buildings from rain during the rainy season. However, these materials tend not to be resistant to fire. 


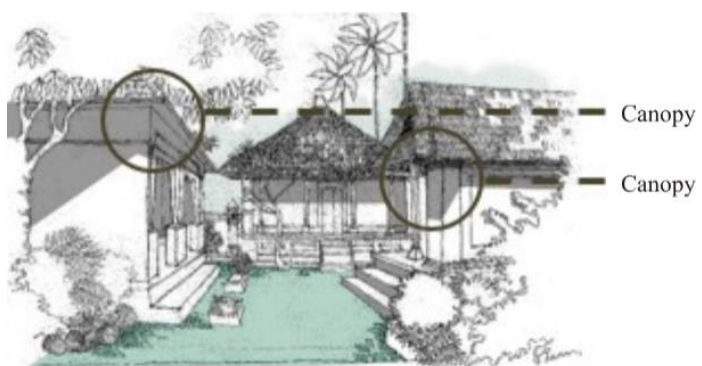

Figure 13. Canopy of Balinese buildings

Source: (Suryada 2012)

The legs illustrate the Balinese population's dependence on the environment and this makes them to be constructed directly adjacent to the land. Moreover, the bataran functions as an intermediary between the environment and the buildings by serving as a barrier to flooding, animals around, and also as the access to the building. However, it is less safe when it rains.

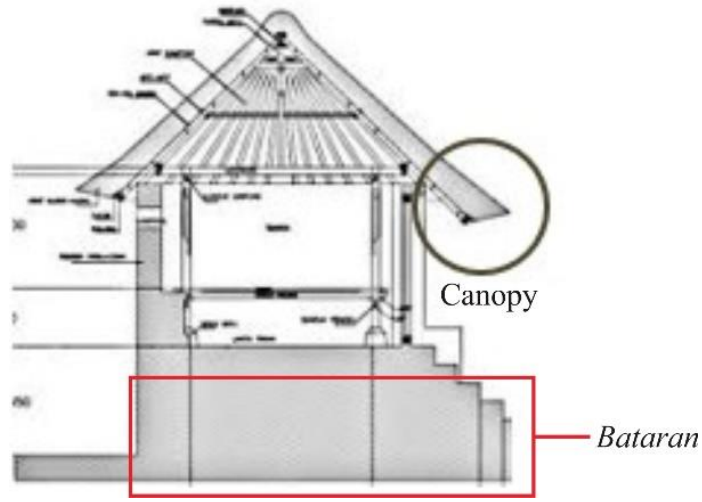

Figure 14. Bataran/grounds in Balinese building Source: (Lanus, Susanta, and Laskara 2017)

K4 (safety, security, health, and sustainability) in theater

Environmental aspects are applied more in buildings to and prevent and protect the environment and surroundings from accidents. In Indonesia, this is usually based on the provisions of SNI-2000 which requires the installation of sprinklers and emergency stairs (Badan Standarisasi Nasional Republik Indonesia 2000).

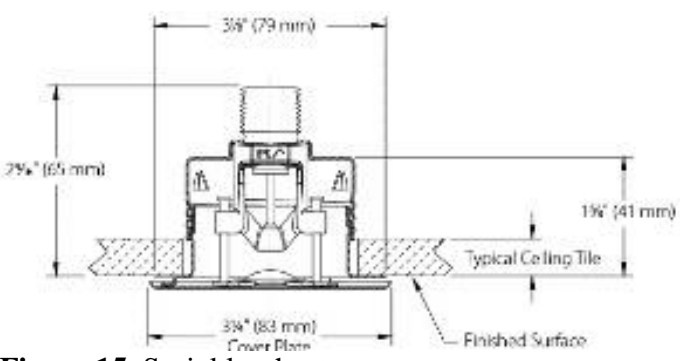

Figure 15. Sprinkler theater

Source: (Badan Standarisasi Nasional Republik Indonesia 2000)

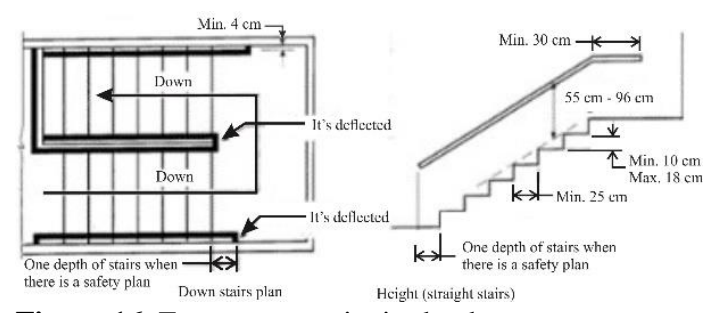

Figure 16. Emergency stairs in the theater

Source: (Badan Standarisasi Nasional Republik Indonesia 2000)

The implementation of environmental aspects

It is possible to implement these aspects from two different perspectives with those associated with the Bali covering the exterior while those related to the theater serve as an interior deterrence.

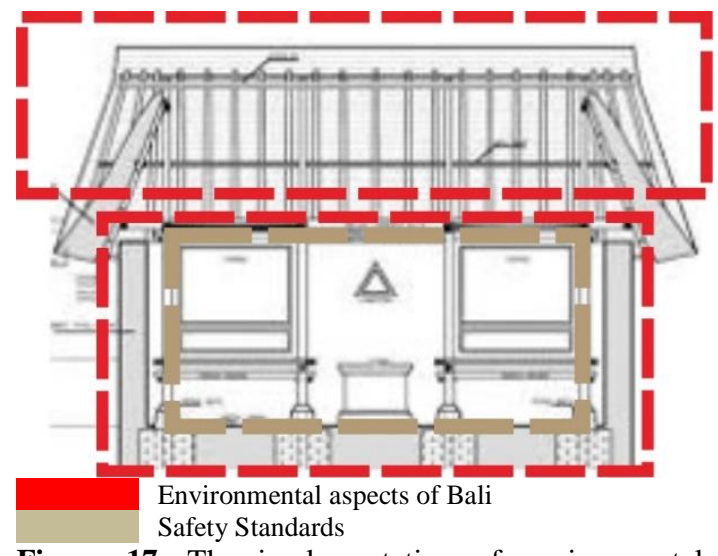

Figure 17. The implementation of environmental aspects

The security can also be implemented by combining traditional Balinese forms with technology. 


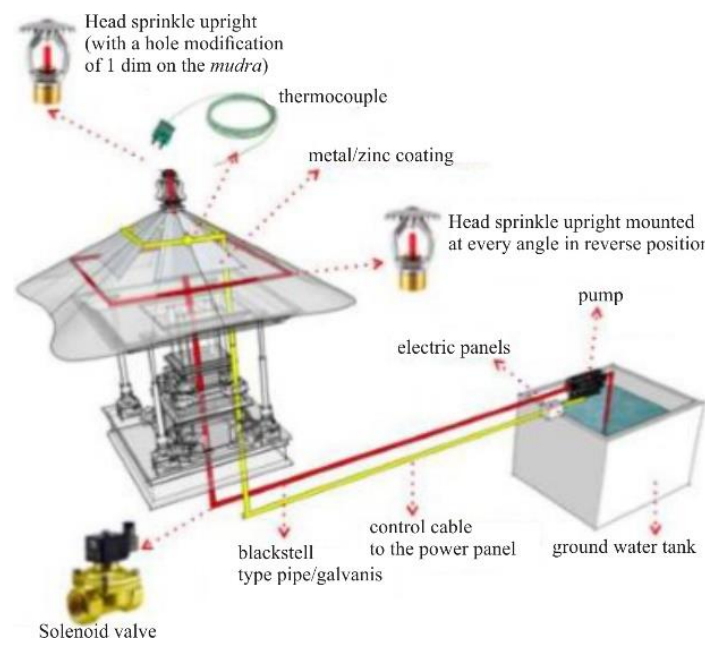

Figure 18. Bali roof with sprinkler

Source: (Gunawarman 2019)

The first implementation is associated with the roof, where traditional Balinese roofs using palm leaf fiber are considered less durable and safe, especially for fire incidence. Therefore, this can be solved with the use of a metal roof as a conductor to provide a sign to the thermocouple connected to the sprinkler such that in a situation of fire occurrence, it would be activated automatically in a short time.

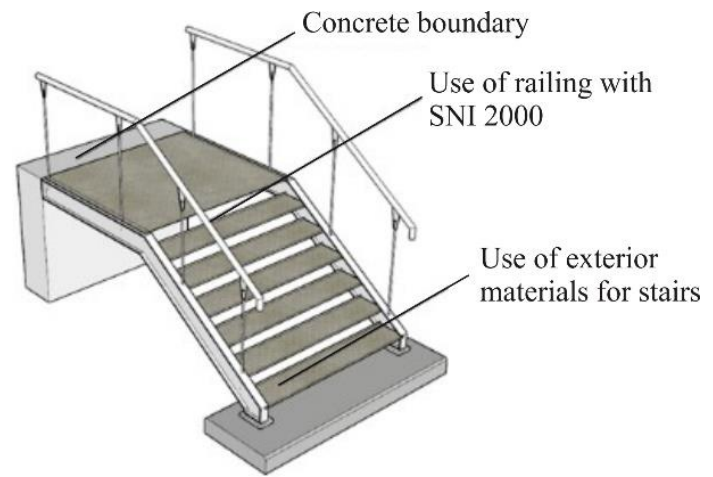

Figure 19. Modifications on Balinese grounds/bataran

The modifications to the bataran can also be complemented with existing SNI standards such as railings, the use of outdoor materials, the height of stairs, additional facilities for disability, and several other standards to make sure it is safer.

\section{Conclusion}

Several conclusions were made based on different aspects towards integrating traditional Balinese architecture in a modern theater and they are as follows: (1) Spatial/layout: The spatial planning analysis showed the traditional Balinese architecture is very concerned about its arrangement due to its relation to the local community's trust and the surrounding environment. Meanwhile, the theater prefers the relationship between its spaces in relation to the working system. Therefore, it is possible to incorporate these functions into plots while planning the Balinese spatial pattern; (2) Sosok/figure: The Balinese figures are represented by the shapes of the three unique existing building parts including the head (roof), body (curved wall), and legs (foundation). Meanwhile, the theater focuses only on the auditorium due to its relation to the comfort enjoyed by visitors during a show. This, therefore, shows the figure demanded for each variable is different with the Balinese architecture observed to be concerned about the covers while the theater emphasizes on its interior; (3) System: In traditional Balinese architecture, it is possible to change the building construction system according to the concept of Village, kala, and patra (depending on the place, time, and condition). This shows uncertainty in the process and domination on the outside of the building which is directly related to nature. The theater system is different because it is more rigid, especially the material. This, therefore, means it can be applied in the Balinese construction using environmentally friendly and safe materials; (4) Environment: The environment in Balinese architecture is more passive and focuses more on the outside of the building. It directly borders with nature such as natural wind flow or open circulation. Meanwhile, the theater tends to adhere to existing regulations for public buildings. They are both, therefore, needed to be combined to suit the Balinese and theater contexts such as the use of fire-resistant materials, gas usage, and automatic sprinklers in firefighting.

The analysis showed different demands from the Balinese traditional architecture which tends towards local community ideology and theater which was observed to be related to acoustic systems and security. It is, therefore, possible to combine both the old and new concepts.

This is possible because the Balinese concept such as village, kala, patra suggests the possibility of continuous changes in the nature of Balinese buildings with time depending on location, time, and circumstances. This is 
essential to ensure the buildings continue to live and develop.

The guidelines obtained include the implementation of theater space in asta kosalakosali Bali with modifications to the roof, body, and legs by combining both Balinese construction systems and theater materials and the use of technology in traditional Balinese buildings. This application is, however, expected to be based on the concept of Tri Hita Karana which is the main basis used by the Balinese people to prioritize the relationship between humans with nature and its creator. This, therefore, means the guidelines on the design need to be implemented on the roof, body, and legs as an embodiment of the concept. They are expected to be made inseparable, for example, apply only the guidelines for the roof without paying attention to the body and legs.

\section{Acknowledgment}

The author praises God Almighty for His graces to ensure the timely completion of this thesis which is a mandatory requirement to graduate from the Department of Architecture, Faculty of Engineering in the 2019/2020 school year.

The author faced several obstacles and barriers while compiling this scientific paper, especially due to the limited time. Therefore, the following people are appreciated for several inputs they made to ensure the success of this thesis: (1) The supervisor and co-supervisor for the help they provide from the beginning to the end of the writing process; (2) The examiner for providing advice and support; (3) The author's parents for their moral and material guidance; (4) My friends that helped a lot in making this research to ensure it was completed on time without problems.

\section{References}

Antoniades, Anthony C. 1990. Poetics of Architecture: Theory of Design. New York City: Van Nostrand Reinhold.

Appleton, Ian. 2012. Buildings for the Performing Arts: A Design and Development Guide. 2nd ed. England, UK: Routledge, Taylor and Francis Group.

Arifin, Zainal. 2017. Evaluasi Pembelajaran: Prinsip, Teknik, Dan Prosedur. Bandung: PT. Remaja Rosdakarya.

Badan Standarisasi Nasional Republik Indonesia. 2000. SNI-03-1746-2000: Tata Cara Perencanaan Dan Pemasangan Sarana Jalan Ke Luar Untuk Penyelamatan Terhadap Bahaya Kebakaran Pada Bangunan Gedung. Indonesia.

https://dinasdamkar.sukabumikab.go.id/2017/ 10/23/sni-03-1746-2000/.

bali.com. n.d. 'Pengaruh Budaya Dalam Arsitektur Bali' Bali.Com. https://www.bali.com/id/arsitektur-bangunanbali.html.

Chiara, Joseph De. 1973. Times Saver Standard for Building Types. London and New York: McGraw-Hill Book Co.

Doelle, Leslie L. 1972. Environmental Acoustics. New York City: McGraw-Hill.

Gelebet, I Nyoman. 1985. Arsitektur Tradisional Daerah Bali. Edited by I. G. N. Arinton Puja. Proyek Inv. Jakarta: Departemen Pendidikan dan Kebudayaan.

Gunawarman, Anak Agung Gede Raka. 2019. 'Konsep Desain Mitigasi Bencana Kebakaran Pada Bangunan Pura Beratap Ijuk'. Jurnal Arsitektur ZONASI 2 (1): 25. https://doi.org/10.17509/jaz.v2i1.15058.

Hitchcock, Henry Russell. 1997. The International Style. United States of America: W. W. Norton \& Company.

Lake, Reginaldo Christophori. 2014. 'Konsep Ruang Dalam Dan Ruang Luar Arsitektur Tradisional Suku Atoni Di Kampung Tamkesi Di Pulau Timor'. E-Journal Graduate Unpar 1 (2): 61-74. http://journal.unpar.ac.id/index.php/unpargra duate/article/view/842/829.

_. 2015. 'Budaya Tektonika Wologai Ende, Nusa Tenggara Timur Sebuah Seni Berkonstruksi Rumah Adat Desa Wologai Tengah, Kecamatan Detusoko, Warisan Leluhur Wawo - Ata Lio Di Bawah Kaki Gunung Lepembusu'. ATRIUM: Jurnal Arsitektur 1 (2): 151-66. https://doi.org/10.21460/atvm.2016.12.15.

- 2016. 'Tata Spasial Arsitektur Tradisional Suku Atoni Di Kampung Tamkesi 
Pulau Timor'. ATRIUM - Jurnal Arsitektur. https://doi.org/10.21460/atvm.2016.21.3.

- 2017. 'Metode Pendekatan Desain Menurut Henry Bergson Dan Gilbert Ryle Terhadap Arsitektur Dekonstruksi'. In Penerapan Ipteks Dalam Mendukung Pembangunan Yang Berkelanjutan, 51-56. Kupang: Prodi Arsitektur Fakultas Teknik Universitas Katolik Widya Mandira.

Lake, Reginaldo Christophori, Fransiscus X. Eddy Arinto, Yohanes Djarot Purbadi, Yohanes Basuki Dwisusanto, Elvis Albertus Bin Toni, and Robertus Mas Rayawulan. 2020. 'Architecture Expression: Synthesized Architectural Expressions in Mayor's Office Building of Kupang City'. Local Wisdom: Jurnal Ilmiah Kajian Kearifan Lokal 12 (2). https://doi.org/10.26905/lw.v12i2.4302.

Lake, Reginaldo Christophori, Yohanes Djarot Purbadi, and Herman Florianus Harmans. 2020. 'Identification and Orientation on Spatial Arrangement of Wajo Traditional Village, Keo Tengah, Nagekeo Regency'. Local Wisdom: Jurnal Ilmiah Kajian Kearifan Lokal 12 (1): 19-30. https://doi.org/10.26905/lw.v12i1.3581.

Lanus, I Nengah, I Nyoman Susanta, and Gede Windu Laskara. 2017. 'Identifikasi Bentuk, Struktur, Dan Konstruksi Bale Meten Sakaulu Pada Arsitektur Tradisional Bali Di Desa Gunaksa, Klungkung'. In Seminar Nasional Arsitektur Dan Tata Ruang 2017 (SAMARTA), 1-35. Bali: Universitas Udayana. https://samartaarsitektur.unud.ac.id/wp-
content/uploads/2018/01/1005-56-I-NengahLanus-I-Nyoman-Susanta.pdf.

Loebis, M. Nawawiy. 2004. Raibnya Para Dewa: Kajian Arsitektur Karo. Medan: Bina Teknik Press.

Made, Waskhita. 2012. 'Bali Tradisional Perlu Di Lestarikan'. Waskhita Made. 2012. http://wahyuprio93.blogspot.com/2012/06/ba li-tradisional-perlu-di-lestarikan-di.html.

Salura, Purnama, and Reginaldo Christophori Lake. 2014. 'The Architectural Language of Inner and Outer Space as Observed among the Atoni Tribe in the Tamkesi Kampong on Timor Island'. International Journal of Academic Research 6 (3). https://doi.org/10.7813/2075-4124.2014/63/a.29.

Sugiyono. 2019. Metode Penelitian Kuatintatif, Kualitatif Dan R\&D. Alfabeta. 2nd ed. Bandung: Alfabeta. https://doi.org/2008.

Sunarta, Nyoman, and Nyoman Sukma Arida. 2017. Pariwisata Berkelanjutan. I. Bali: Cakra Press. https://simdos.unud.ac.id/uploads/file_pendid ikan_1_dir/81eee6c1d3a49690e16b3be3dfb9 855f.pdf.

Suryada, I Gusti Agung Bagus. 2012. 'Konsepsi Tri Mandala Dan Sanga Mandala Dalam Tatatan Arsitektur Tradisional Bali'. Sulapa 4 (1): 23-32. https://simdos.unud.ac.id/uploads/file_riwaya t_penelitian_1_dir/3d34586bfb9a13b1aa4c78 e3bbe785e4.pdf.

Wijaya, I Kadek Merta. 2016. 'Telaah Arsitektur Vernakular Pada Artikel: The Balinese Christian Settlement And Church Architecture As A Model Of Inculturation'. WICAKSANA Jurnal Lingkungan 25 (1): 1-12. http://repository.warmadewa.ac.id/id/eprint/1 90/. 